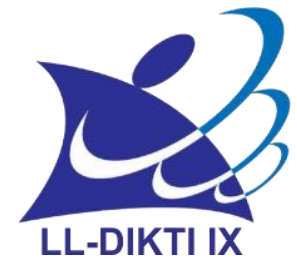

\title{
Pengolahan Dan Pemasaran Online Produk Susu Kefir Di Desa Gunung Perak Kabupaten Sinjai
}

\author{
Hadrianti H. D. Lasari ${ }^{1}$, Safaruddin ${ }^{2}$, Ka'bah $^{3}$ \\ ${ }^{1}$ Kesehatan Masyarakat, Universitas Lambung Mangkurat \\ Email: hadrianti.lasari@ulm.ac.id \\ 2 Farmasi, Universitas Megarezky \\ ${ }^{3}$ Analisis Kesehatan, Universitas Megarezky
}

\section{Artikel info}

\section{Artikel history:}

Received;September-2019

Revised: September-2019

Accepted;Oktober-2019

Publish: Oktober-2019

\section{Keywords:}

Cow Milk;

Kefir;

Marketing Online;

Gunung Perak

Village;
Abstract. The potential of this agribusiness can be found and developed in Gunung Perak Village. In the village fresh milk is produced which is then processed in the Sintari Dairy Cooperative, better known as Susin. Aiming at product innovation, the community service team conducted this Community Service Activity smoothly for five months. Participants in this activity generally work as teaching teachers, housewives and farmers. This activity is dominated by participants aged 18-45 years and $100 \%$ participants are female. This activity was also followed by PKK in Gunung Perak Village. Mc Nemar X2 test with a Significant value of $0.007<0.05$ so that there are differences in knowledge before and after exposure to material about Processing and Online Marketing of Kefir Dairy Products in Gunung Perak Village, West Sinjai District, Sinjai District. This activity, public knowledge increased by an average value difference of 1.88 with the addition of knowledge reaching $9.4 \%$.

\section{Coresponden author:}

Email: hadrianti.lasari@ulm.ac.id

artikel dengan akses terbuka dibawah lisensi CC BY -4.0

\section{PENDAHULUAN}

Sulawesi Selatan memiliki berbagai kekayaan yang sangat beraneka ragam. Salah satu kekayaan yang dimiliki oleh provinsi yang berada di Indonesia Timur ini adalah potensi usaha agribisnis pengolahan susu sapi. Potensi tersebut dikembangkan di Desa Gunung Perak yang berada di ketinggian 1100 meter dari permukaan laut.

Sapi perah yang dipelihara di Desa Gunung Perak tepatnya di Koperasi Susu Sintari, kelompok tani Batu Leppa berjumlah 16 ekor. Seiring dengan perkembangan peternakan di desa tersebut, mendorong masyarakat untuk membentuk kelompok tani yang berguna untuk menunjang keberhasilan usaha peternakan sapi perah di desa tersebut.

Kelompok tani terdapat di 5 desa, yakni Desa Gunung Perak (Batu Leppa, Tambalahulung dan Kariango Lestari), Barania (Pattiroang, Maddakko, Bukit Indah dan Mekar Jaya), Botolempangan (Paggalaangia), Balakia (Bunga Siria) dan Tassililu (Kalotoro dan Lappara`na). Selama beberapa tahun berproduksi, jumlah kelompok tani semakin berkurang dan 
hingga saat ini tersisa 3 kelompok tani yang masih produktif yakni kelompok tani Batu Leppa, Pattiroang dan Kalotoro. Ketiga kelompok tani tersebut, setiap harinya memproduksi susu segar yang kemudian dilakukan pengolahan di Koperasi Susu Sintari yang lebih dikenal dengan Susin. Susin merupakan produk lokal andalan Kabupaten Sinjai yang telah banyak didistribusikan di luar Kabupaten Sinjai, misalnya di Makassar. Susin merupakan susu segar yang diolah dengan proses pasteurisasi, sehingga dapat bertahan lama hingga seminggu tanpa mengurangi kandungan nutrisi susu tersebut (Yusuf, 2011)

Susu merupakan bahan minuman yang sesuai untuk kebutuhan hewan dan manusia karena mengandung zat gizi dengan perbandingan yang optimal, mudah dicerna dan tidak ada sisa yang terbuang. Selain sebagai sumber protein hewani, susu juga sangat baik untuk pertumbuhan bakteri. Kriteria air susu sapi yang baik setidaktidaknyamemenuhi hal-hal s ebagai berikut bebas dari bakteri pathogen, bebas dari zat-zat yang berbahaya ataupun toksin seperti insektisida, tidak tercemar oleh debu dan kotoran, (iv) zat gizi yang tidak menyimpang dari codex air susu, dan memiliki cita rasa normal. Zat-zat gizi yang terkandung dalam susu sapi segar (Resnawati, n.d.).

Susu sterilisasi adalah produk olahan susu yang diperoleh melalui suatu proses membunuh mikroorganisme hingga ke spora-sporanya. Proses sterilisasi dilakukan dengan cara memanaskan susu hingga temperatur $121^{\circ} \mathrm{C}$, selama kurun waktu 15 menit

Susu sapi segar di Desa Gunung Perak Kabupaten Sinjai memiliki daya tahan yang relatif singkat untuk sampai di Kota Makassar. Padahal, dengan pengolahan susu sapi segar menjadi produk susu kefir akan menjaga keawetan susu sapi sehingga lebih produktif dan ekonomis.

Pengabdian masyarakat ini akan difokuskan di Desa Gunung Perak tepatnya pada kelompok tani Batu Leppa yang notabene masih produktif. Pengabdian masyarakat ini diharapkan mampu meningkatkan perekonomian masyarakat setempat dengan memaksimalkan potensi susu sapi perah yang dimilikinya. Diversifikasi atau penganekaragaman produk olahan susu merupakan salah satu upaya meningkatkan konsumsi susu bagi masyarakat dan berguna bagi produsen dan berbagai pihak yang terkait dalam kegiatan agribisnis dan agroindustri persusuan (Hendrawati \& Utomo, 2017)

Produk kefir dinilai memiliki nilai jual yang tinggi dan kandungan gizi yang lebih baik daripada susu perah murni. Kefir merupakan salah satu jenis susu fermentasi yang dibuat dengan starter granula kefir. Kefir memiliki kekentalan seperti krim serta memiliki rasa asam dan beralkohol (Safitri \& Swarastuti, 2011)

Selain itu produk kefir merupakan salah satu teknologi pascapanen yang merupakan salah satu upaya untuk meningkatkan mutu dan keamanan susu segar selain penerapan manajemen mutu pada tahap pemerahan, penanganan, pengolahan, pengemasan, penyimpanan dingin dan transportasi (Abubakar, 2012). Mengapa susu kefir sehat, karena Susu fermentasi merupakan produk yang relative kental dan lambat melewati saluran pencernaan. Keadaan tersebut menyebabkan waktu tinggal dalam saluran pencernaan menjadi lama sehingga penyerapan nutrisi akan lebih banyak (Usmiati \& Ram, 2005).

Menurut Menteri Pertanian, tingkat konsumsi susu segar masyarakat Indonesia perlu terus ditingkatkan, selain untuk menjaga kesehatan, mengkonsumsi susu dapat mencerdaskan. Sampai saat ini pemasok susu terbesar di Indonesia berasal dari pulau Jawa, dari 95 koperasi susu di Pulau Jawa, 45 berada di Jawa Timur, 25 di Jawa Tengah dan 25 di Jawa Barat dengan produksi 1-1,2 juta liter/hari. Jumlah ini akan bertambah seiring dengan kenaikan harga susu, karena adanya kesadaran para peternak dan pengusaha untuk meningkatkan jumlah sapi perah sebagai lahan bisnis yang menguntungkan (Abubakar, 2012).

Perkembangan teknologi informasi terutama Internet, merupakan faktor pendorong perkembangan e-commerce. Internet merupa- kan jaringan global yang menyatukan jaringan komputer di seluruh dunia, sehingga memung- kinkan terjalin-nya komunikasi dan interaksi antara satu dengan yang lain diseluruh dunia. Dengan menghubungkan jaringan komputer perusahaan dengan Internet, perusahaan dapat menjalin hubungan bisnis dengan rekan bisnis atau konsumen secara lebih efisien. Sampai saat ini Internet merupakan infrastruktur yang ideal untuk menjalankan e-commerce, sehingga istilah e-commerce pun menjadi identik dengan menjalankan 
bisnis di Internet. Dengan jumlah pengguna Internet yang mencapai angka 82 juta orang atau sekitar 30\% dari total penduduk di Indonesia, pasar e-commerce menjadi tambang emas yang sangat menggoda bagi sebagian orang yang bisa melihat potensi kedepannya.

Pertumbuhan ini didukung dengan data dari Menkominfo yang menyebutkan bahwa nilai transaksi e-commerce pada tahun 2013 mencapai angka Rp130 triliun. Pasar bisnis perdagangan elektronik diperkirakan akan terus tumbuh dengan meningkatnya infrastruktur pendukung Internet di Indonesia. Data dari lembaga riset ICD yang mempunyai kantor pusat di London UK ini memprediksi bahwa pasar e-commerce di Indonesia tumbuh $42 \%$ dari tahun 2012-2015 (Reza, 2016).

UKM yang ada di Indonesia masih menghadapi berbagai masalah antara lain masalah promosi, pemasaran dan penjualan penjaualan produk yang dihasilkan. Misalnya pemasaran susu sapi segar di Desa Gunung Perak menggunakan teknik pemasaran dari mulut ke mulut serta informasinya dapat diakses di Dinas Peternakan. Keterbatasan pemasaran susu sapi segar di desa tersebut pada upaya pemasaran online sehingga Desa Gunung Perak sebagai desa penghasil susu segar sapi masih kurang dikenal oleh masyarakat luas di Indonesia.

Masalah utama yang dihadapi oleh UKM adalah pemasaran. Pemasaran dengan metode konvensional memerlukan biaya tinggi, misalnya membuka cabang baru, ikut pameran, pembuatan dan penyebaran brosur dan sebagainya. Pendampingan masalah promosi, pemasaran dan penjualan penjaualan produk yang dihasilkan perlu diupayakan sebagai wujud tanggung jawab sosial dalam meningkatkan kesejahteraan masyarakat pedesaan.

\section{Metode}

Pelaksanaan pengabdian masyarakat ini adalah pendampingan dan pemberdayaan masyarakat menggunakan strategi kemitraan. Kemitraan adalah upaya untuk melibatkan berbagai sektor kelompok masyarakat, lembaga pemerintah maupun bukan pemerintah, untuk bekerja sama dalam mencapai tujuan bersama berdasarkan atas kesepakatan prinsip dan peranan masing-masing. Kemitraan adalah suatu kerja sama yang formal antara individu-individu, kelompok- kelompok atau organisasi untuk mencapai tujuan tertentu. Adapun tujuan kemitraan diantaranya: meningkatkan koordinasi untuk memenuhi kewajiban peran masing -masing dalam pembangunan kesehatan, meningkatkan komunikasi antarsektoral, meningkatkan kemampuan bersama dalam menanggulangi masalah kesehatan dan memaksimalkan keuntungan semua pihak, meningkatkan apa yangg menjadi komitmen bersama, tercapainya upaya kesehatan yang efisien dan efektif. Dengan memaksimalkan produk kefir untuk masyarakat dapat memberikan dampak peningkatan derajat kesehatan masyarakat.

Adapun langkah-langkah membangun kemitraan yaitu:

1. Penjajakan yaitu penjajakan calon mitra, sebelumnya dilakukan identifikasi mitra yg potensial diajak dalam rangka pemecahan masalah.

2. Penyamaan persepsi yaitu tujuannya agar mitra memahami satu dengan yg lain, terutama tugas, peran, dan fungsi masing-masing.

3. Pengaturan peran yaitu pengaturan peran harus dibicarakan bersama, serta dituangkan dalam kesepakatan tertulis

4. Komunikasi intensif yaitu komunikasi antar mitra secara teratur dan terjadwal.

5. Pelaksanaan (Monitoring)

6. Pelaporan (Evaluasi)

7. Publikasi hasil pelaksanaan

Pengabdian masyarakat ini merupakan bagian dari upaya pemberdayaan yang tak lain sebagai suatu proses aktif dimana masyarakat yang diberdayakan harus berperan serta dalam berbagai kegiatan.Tahapan dan langkah-langkah untuk Program Kemitraan Masyarakat (PKM) produk kefir di desa Gunung Perak yaitu: Perizinan Pengabdian Masyarakat di Kabupaten Sinjai: Tingkat Kabupaten, Kecamatan dan Desa, Koordinasi dengan Dinas Peternakan Kabupaten Sinjai, Persiapan alat, bahan dan materi program pembuatan produk susu kefir, Sosialisasi cara pengolahan produk kefir pada kelompok tani, Diskusi dan Indepth 
104| Celebes Abdimas: Jurnal Pengabdian Kepada Masyarakat

interview dengan kelompok tani, Pengenalan hasil olahan kefir seperti; es krim, kosmetik berupa masker wajah. lulur dan cairan pembersih wajah, Praktik pembuatan produk olahan susu kefir bersama kelompok tani, Pengenaalan Pemasaran secara online hasil produk susu kefir via online, Tutorial pemasaran secara online menggunakan wordpress, maupun sosial media, dan Evaluasi kegiatan pengabdian masyarakat.

\section{Hasil Dan Pembahasan Gambaran Lokasi Kegiatan}

Secara Geografis Desa Gunung Perak Terletak di Koordinat Bujur : 119.978878 Dan Koordinat Lintang : -5.297784, Serta Ketinggian Diatas Permukaan Laut : 1500 Meter. Luas wilayah Desa Gunung Perak, Kecamatan Sinjai barat yaitu 3510,96 Hektar. Dengan batas-batas sebagai berikut :

Sebelah Utara : Berbatasan Dengan Kel. Tassililu, Desa Arabika Dan Kel. Balakia

Sebelah Timur : Berbatasan Dengan Kec. Sinjai Borong Desa Batu Belerang

Sebelah Selatan : Berbatasan Dengan Kabupaten Gowa Dan Bulukumba

Sebelah Barat : Berbatasan Dengan Kabupaten Gowa

Adapun Pembagian Wilayah dusun di Desa Gunung Perak adalah :

a. Dusun Lembang Sihalia

b. Dusun Lembanna

c. Dusun Batu Leppa

d. Dusun Puncak

e. Dusun Tassoso

f. Dusun Bonto Manai

Masyarakat Desa Gunung Perak mayoritas suku Bugis yang mata pencahariannya adalah petani ,selain itu masyarakat masih banyak . Aktifitas masyarakat utamanya acara pengangtin dan Panen hasil pertanian masih menganut pada adat istiadat orang terdahulu yakni Massikiri dan Manre Ase Baru yang dimaknai dengan Rasa syukur atas keberhasilan usaha yang mereka lakukan.

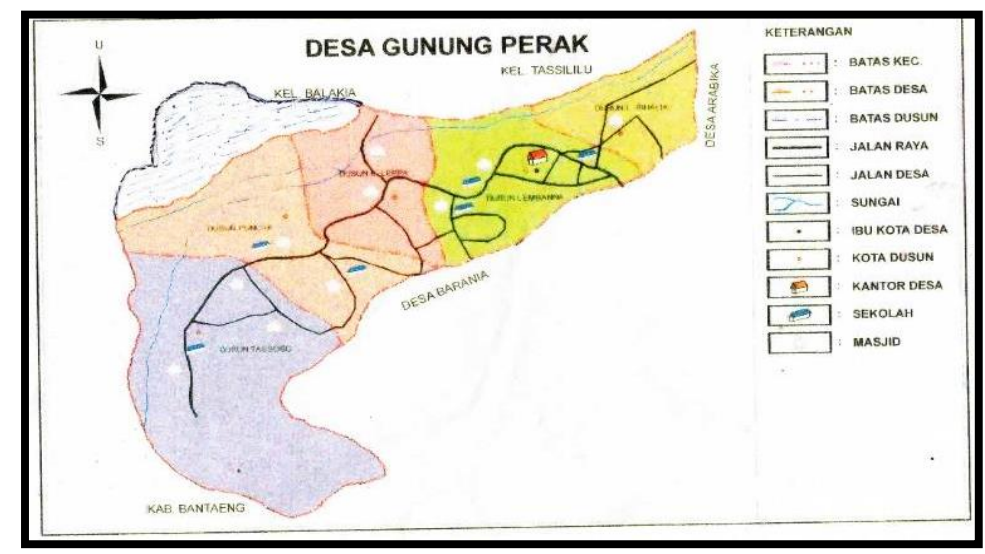

Gambar 1. Peta Desa Gunung Perak, Kecamatan Sinjai Barat Kabupaten Sinjai, Provinsi Sulawesi Selatan

\section{Gambaran Pelaksanaan Kegiatan}

Kegiatan Pengabdian Masyarakat "Pengolahan Dan Pemasaran Online Produk Susu Kefir Di Desa Gunung Perak Kecamatan Sinjai Barat Kabupaten Sinjai" berjalan dengan lancar selama lima bulan. Terhitung sejak bulan April 2019 hingga bulan Agustus 2019.

Peserta kegiatan ini umumnya berprofesi sebagai guru pengajar, ibu rumah tangga dan petani. Kegiatan ini didominasi oleh peserta berumur 18-45 tahun dan 100\% peserta berjenis kelamin perempuan. Kegiatan ini juga diikuti oleh ibu-ibu PKK Desa Gunung Perak. Umumnya peserta berlatar belakang pendidikan Sarjana, namun adapula yang berpendidikan terakhir SMA.

Pengabdian masyarakat ini awalnya mendapatkan dukungan dari mitra penggiat susu sapi di Desa Gunung Perak. Dalam praktiknya, mitra memberikan informasi mengenai produksi susu 
sapi di Koperasi Sintari. Dalam proses pembuatan produk olahan susu kefir, mitra menyediakan kebutuhan susu sapi murni. Namun, dalam pelaksanaannya, perangkat pemerintah Desa Gunung Perak juga memberikan dukungan yang luar biasa dalam penyelenggaraan kegiatan ini.

Kepala Desa Gunung Perak memberikan fasilitas tempat/gedung aula kantor desa. Tak hanya dukungan berupa fasilitas, namun pihak desa bekerjasama dengan Ibu-ibu PKK mengajak masyarakat terlibat aktif dalam kegiatan ini.

Selain komunitas penggiat susu sapi, Pemerintah Desa Gunung Perak, Ibu-ibu PKK, kegiatan ini juga mendapat dukungan dari Gapura Digital dan Women Will. Dukungan yang diberikan berupa panduan pemasaran digital yang dapat diterapkan oleh ibu-ibu yang akan memulai bisnis produk olahan kefirnya. Melalui panduan tersebut, peserta diajarkan untuk menetukan target usaha, meningkatkan efektivitas kerja, menemukan pelanggan baru, mengembankan peluang bisnis, membuat identitas merek, hingga menyentuh Google Bisnis.

Dengan hadirnya pengabdian masyarakat ini, peserta merasa antusias dan bersemangat mengikuti materi yang diberikan. Walaupun mereka memiliki pekerjaan lainnya, peserta masih menyempatkan waktunya untuk hadir dalam acara ini. Beberapa peserta mendiskusikan hasil percobaan yang mereka lakukan di grup whatsapp messengger. Dan tim abdimas akan memberikan penjelasan melalui grup tersebut. Gapura Digital dan Women Will juga aktif memberikan informasi mengenai pelatihan pemasaran online yang rutin dilaksanakan oleh komunitas ini.

Pada pengabdian masyarakat ini, tim abdimas memberikan kuesioner pre dan post untuk mengukur pengetahuan peserta sebelum dan setelah mengikuti pelatihan ini. Sebelum mendapatkan empat materi, peserta wajib mengisi kuesioner yang telah diberikan. Berikut hasilnya:

1. Rata-rata Pengetahuan Peserta Sebelum dan Setelah Pemaparan Materi

Tabel 1. Nilai Mean, Median dan Modus Pengetahuan Peserta Pengabdian Masyarakat di Desa Gunung Perak, Kecamatan Sinjai Barat Nilai Pengetahuan

\begin{tabular}{rcc} 
& \multicolumn{2}{c}{ Nilai Pengetahuan } \\
\hline \multirow{2}{*}{ Nilai } & \multicolumn{2}{c}{ Pengetahuan } \\
\cline { 2 - 3 } & Pre Test & Post Test \\
\hline \multirow{2}{*}{ Mean } & 16,94 & 18,82 \\
\hline
\end{tabular}

Sumber: Data Primer, 2019

Berdasarkan Tabel 1 dapat diamati bahwa terdapat perbedaan rata-rata pengetahuan peserta Pengabdian Masyarakat di Desa Gunung Perak, Kecamatan Sinjai Barat yang sebelum pemberian materi memiliki nilai rata-rata 16,94 dan setelah mendapatkan materi memiliki nilai rata-rata 18,82 . Hal ini memperlihatkan adanya peningkatan pengetahuan peserta mengenai Pengolahan Dan Pemasaran Online Produk Susu Kefir Di Desa Gunung Perak Kecamatan Sinjai Barat Kabupaten Sinjai" dengan selisih nilai rata-rata 1,88.

2. Pengetahuan Peserta Sebelum Pemaparan Materi

Tabel 2. Pengetahuan Peserta Pengabdian Masyarakat di Desa Gunung Perak, Kecamatan Sinjai Barat Sebelum Pemaparan Materi

\begin{tabular}{ccc} 
Pengetahuan & Frekuensi & $\%$ \\
\hline Baik & 22 & 44 \\
Kurang & 28 & 56 \\
Total & 50 & 100 \\
\hline
\end{tabular}

Sumber: Data Primer, 2019

Berdasarkan Tabel 2, pengetahuan peserta sebelum mendapatkan pemaparan materi tentang Pengolahan Dan Pemasaran Online Produk Susu Kefir, pengetahuan berkategori baik $44 \%$ dan kategori kurang $56 \%$. 
106| Celebes Abdimas: Jurnal Pengabdian Kepada Masyarakat

3. Pengetahuan Peserta Setelah Pemaparan Materi

Tabel 3. Pengetahuan Peserta Pengabdian Masyarakat di Desa Gunung Perak, Kecamatan Sinjai Barat Sebelum Pemaparan Materi

\begin{tabular}{ccc} 
Pengetahuan & Frekuensi & $\%$ \\
\hline Baik & 43 & 86 \\
Kurang & 7 & 14 \\
Total & 50 & 100 \\
\hline
\end{tabular}

Sumber: Data Primer, 2019

Berdasarkan Tabel 3, pengetahuan peserta setelah mendapatkan pemaparan materi tentang Pengolahan Dan Pemasaran Online Produk Susu Kefir, pengetahuan berkategori baik 86\% dan kategori kurang $14 \%$.

4. Perbedaan Pengetahuan Sebelum dan Setelah Pemaparan Materi

Tabel 4. Perbedaan Pengetahuan Peserta Pengabdian Masyarakat di Desa Gunung Perak, Kecamatan Sinjai Barat Sebelum dan Setelah Pemaparan Materi

\begin{tabular}{ccccc}
\hline \multirow{2}{*}{ Pre Test } & \multicolumn{2}{c}{ Post Test } & \multirow{2}{*}{ Total } & $\%$ \\
\cline { 2 - 3 } & Kurang & Baik & & $\%$ \\
\hline Kurang & 6 & 22 & 28 & 56 \\
Baik & 1 & 21 & 22 & 44 \\
Total & 7 & 45 & 50 & 100 \\
$\%$ & 14 & 86 & & \\
\hline
\end{tabular}

Sumber: Data Primer, 2019

Berdasarkan Tabel 4 di atas, pada saat pre test, peserta dendengan pengetahuan kategori baik mencapai angka $44 \%$ sedangkan pada saat post test pengetahuan peserta berkategori baik mencapai angka 86\%. Jadi terdapat peningkatan jumlah peserta yang memiliki pengetahuan berkategori baik yakni $42 \%$.

5. Perbedaan Pengetahuan Sebelum dan Setelah Pemaparan Materi

Tabel 5. Uji X2 Mc Nemar untuk mengetahui perbedaan Pengetahuan Sebelum dan Setelah Pemaparan Materi

\begin{tabular}{lr}
\hline \multicolumn{2}{c}{ Test Statistics } \\
\hline \multicolumn{1}{c}{ Pre Test \& Post Test $^{\mathbf{a}}$} \\
\hline $\mathrm{N}$ & 50 \\
Chi-Square & 7,259 \\
Asymp. Sig. & 0,007 \\
a. McNemar Test & \\
b. Continuity Corrected & \\
\hline
\end{tabular}

Sumber: Data Primer, 2019

Berdasarkan Tabel 5 disimpulkan bahwa ada perbedaan pengetahuan sebelum dan setelah pemaparan materi tentang Pengolahan Dan Pemasaran Online Produk Susu Kefir di Desa Gunung Perak, Kecamatan Sinjai Barat, Kabupaten Sinjai. Hal ini dibuktikan dengan uji X2 Mc Nemar dengan nilai Signifikan 0,007 $<0,05$ sehingga ada perbedaan pengetahuan sebelum dan setelah pemaparan materi tentang Pengolahan Dan Pemasaran Online Produk Susu Kefir di Desa Gunung Perak, Kecamatan Sinjai Barat, Kabupaten Sinjai. Kegiatan ini terbagi menjadi empat tahap yaitu : a. Tahap persiapan yang meliputi

Rapat koordinasi dengan tim pengabdian masyarakat dan penandatanganan fakta integritas tim abdimas. Kemudian Pengurusan izin penelitian dari tingkat Provinsi Sulawesi Selatan kemudian tingkat kabupaten Sinjai , lalu ke tingkat Kecamatan Sinjai Barat dan berakhir di tingkat Desa Gunung Perak. Menyiapkan materi pengadian masyarakat yang terdiri dari empat materi yaitu 
segudang manfaat susu kefir, prosedur pembuatan susu kefir, pemasaran offline dan online (konsep pemasaran, manfaat dan media pemasaran), contoh aneka olahan produk kefir. Menyiapkan kuesioner pre dan post test untuk melihat peningkatan pengetahuan sebelum dan setelah kegiatan pengabdian masyarakat. Menyiapkan formulir pendaftaran yang dibagikan kepada masyarakat Desa Gunung Perak. Menyiapkan alat dan bahan untuk praktik pembuatan produk susu kefir seperti: starter bibit kefir, penyaring, spatula plastik, toples, kain lap kering, wadah/ conto kemasan siap pakai untuk hasil olahan produk, paket data internet, souvenir untuk peserta, souvenir untuk Desa Gunung Perak, reagen untuk pembuatan kosmetik, dan spanduk.

\section{b. Tahap Pelaksanaan}

Berkoordinasi dengan Kepala Desa Gunung Perak mengenai jadwal pelaksanaan pengabdian masyarakat dan disepakati kegiatan sosialisasi dan cek lokasi tertanggal 27 Mei 2019. Lalu kegiatan tahap berikutnya, pemberian materi pengabdian dan praktik pembuatan tertanggal 910 Juli 2019. Kemudian tahap evaluasi pengabdian masyarakat tertanggal 1 Agustus 2019. Sosialisasi kegiatan abdimas kepada masyarakat dan cek lokasi di Desa Gunung Perak. Berkunjung sekaligus mengungjungi Koperasi Susu Sintari yang merupakan penghasil susu sapi murni. Dalam kegiatan tersebut tim berdiskusi dengan salah satu penggiat susu sapi tentang produksi susu sapi di desa tersebut.

Melaksanakan kegiatan inti pengabdian masyarakat yang terdiri dari :

- Memberikan kuesioner pre test dengan jumlah soal sebanyak 20 butir kepada peserta pengabdian masyarakat berjumlah 50 peserta.

- Memberikan materi kepada peserta tentang : segudang manfaat susu kefir, prosedur pembuatan susu kefir, pemasaran offline dan online (konsep pemasaran, manfaat dan media pemasaran), contoh aneka olahan produk kefir. Juga tambahan materi dari Gapura Digital dan Women Will dengan topik "Merencanakan Pemasaran Digital".

- Membentuk grup whatssapp messenger untuk memudahkan diskusi anatar tim abdimas dan peserta. Mengingat jarak yang cukup jauh yakni jarak tempuh $130 \mathrm{Km}$ dari Kota Makassar.

- Memberikan souvenir kenang-kenangan kepada peserta, starter bibit kefir, kemasan siap pakai serta paket data internet.

- Demonstrasi pembuatan susu kefir menggunakan alat seperti toples, penyaring, spatula dan lap kering dan susu sapi murni Desa Gunung Perak yang diambil dari Koperasi Sintari.

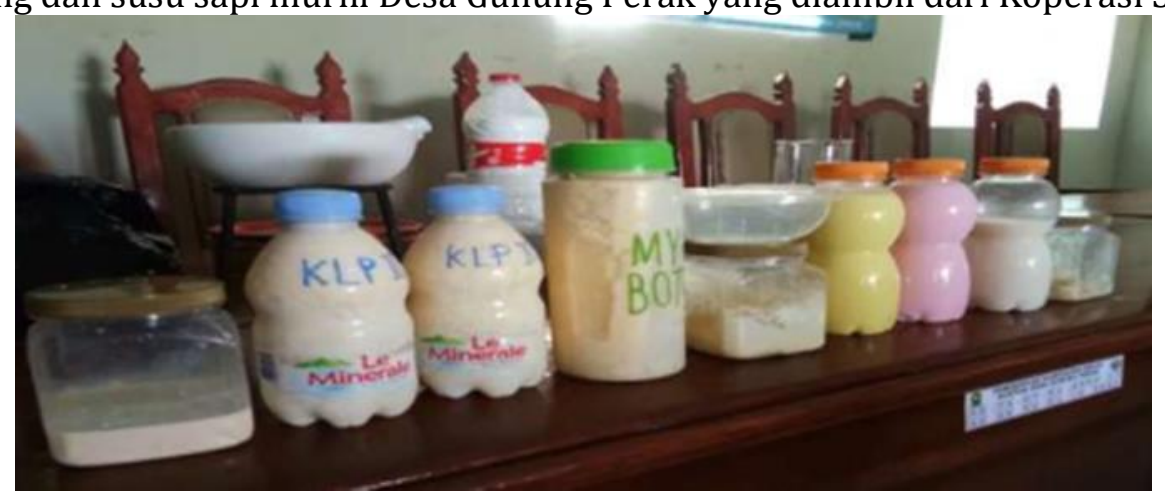

Gambar 2. Tahap Pelaksanaan Pembuatan Susu Kefir di Desa Gunung Perak

\section{c. Melaksanakan tahap evaluasi pengabdian masyarakat yang terdiri dari :}

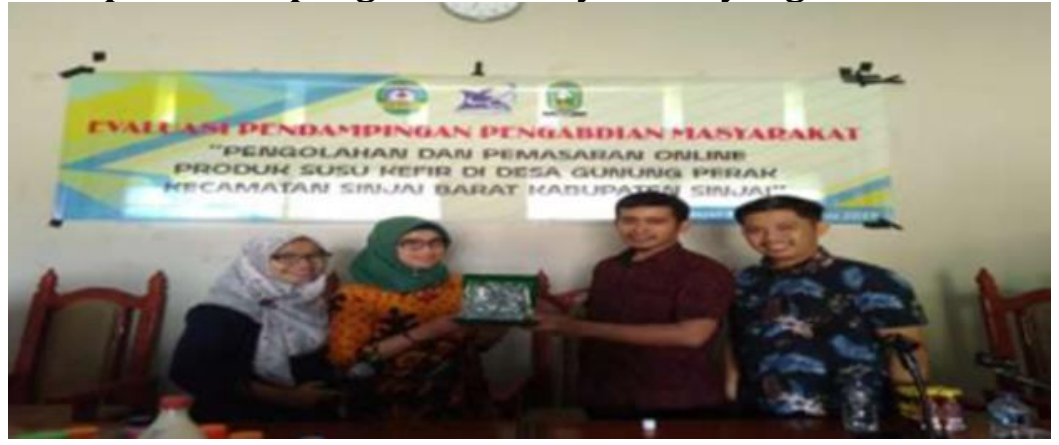


108| Celebes Abdimas: Jurnal Pengabdian Kepada Masyarakat

\section{Gambar 3. Tahap Evaluasi Pengabdian Masyarakat di Desa Gunung Perak}

Kegiatan yang dilakukan diantaranya praktik pembuatan produk kefir seperti lotion dan scrub oleh peserta untuk mengingatkan kembali materi yang telah diberikan pada tahap sebelumnya. Memberikan kuesioner post test dengan jumlah soal sebanyak 20 butir kepada peserta pengabdian masyarakat berjumlah 50 peserta. Melakukan umpan balik kepada peserta mengenai materi yang telah diberikan pada tahap sebelumnya. Memberikan souvenir kenangkenangan kepada Desa Gunung Perak. Dan menutup kegiatan abdimas ditandai dengan diterbitkannya surat keterangan telah melakukan kegiatan abdimas di Desa Gunung Perak Kecamatan Sinjai Barat, Kabupaten Sinjai, Provinsi Sulawesi Selatan.

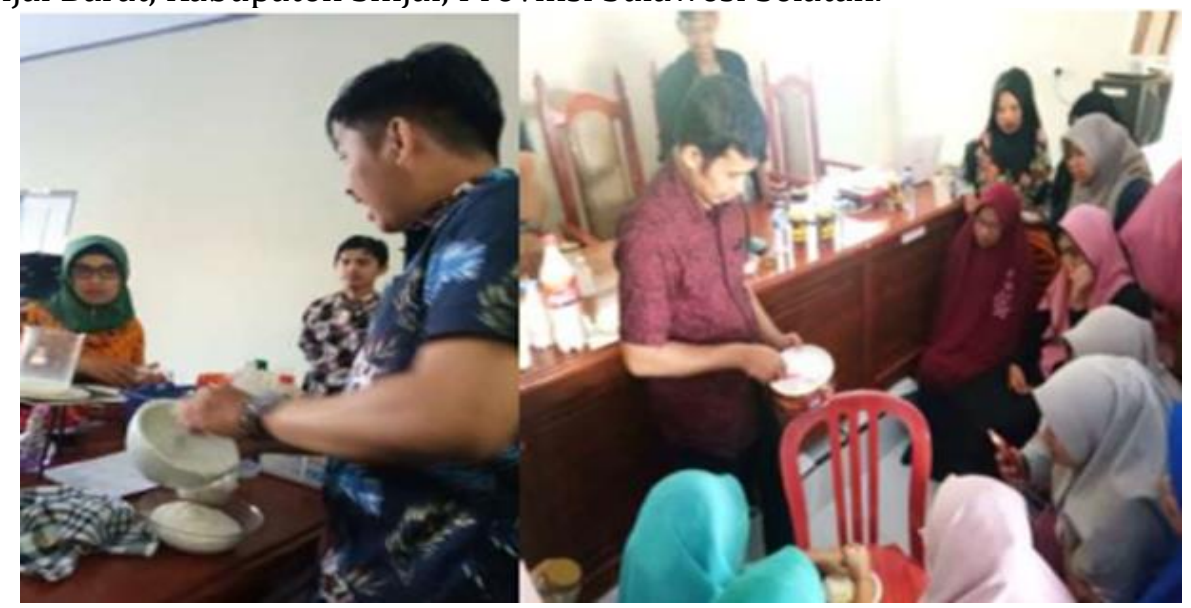

Gambar 4. Tahap Evaluasi dan Praktik Pembuatan Produk Kefir

\section{d. Pengolahan data kuesioner}

Tim pengabdian masyarakat melakukan rekap score jawaban dari 20 pertanyaan kuesioner. Tim merekap nilai sebelum peserta mendapatkan pemaparan materi, kemudian score jawaban kuesioner setelah pemaparan materi direkap juga. Score tersebut dikategorikan menjadi dua yaitu pengetahuan baik dengan kode 1 dan pengetahuan kurang dengan kode 2 . Berkategori baik bila nilai median scorenya $\geq 17$, sedangkan kurang bila nilai median scorenya $<16,99$. Setelah pengetahuan responden dikategorikan, kemudian selanjutnya diuji menggunakan chi square Mc Nemar untuk melihat perbedaan pengetahuan sebelum dan setelah pemaparan materi. Waktu pengukuran pengetahuan, kuesioner sebelum dan setelah berjarak selama 21 hari atau 3 minggu. Konten materi pengabdian masyarakat yang diberikan dalam kegiatan tersebut adalah

a. Segudang Manfaat Susu Kefir,

Pemateri memaparkan beberapa manfaat produk kefir seperti Kefir kerap digunakan untuk meningkatkan cita rasa segala jenis masakan. Tak hanya itu, kefir juga banyak digunakan dalam dunia kosmetik, khususnya untuk masker dan gel. Pemateri juga menyampaikan pemanfaatan kefir untuk kosmetik misalnya meminum kefir dengan kayu manis membantu membakar lemak - cukup tambahkan sejumput kayu manis dalam segelas kefir. Anda juga bisa menambahkan madu atau parutan jahe. Selain itu, Minum kefir dengan biji flax pada malam hari membantu melancarkan sistem pencernaan, menstabilkan fungsi hari, serta melancarkan sirkulasi darah. Tambahkan satu sendok teh biji flax ke dalam segelas kefir. Dalam kesempatan itu, pemateri juga menyampaikan formula dasar pembuatan lotion berbahan dasar kefir, serta membuat basis cream.

b. Prosedur Pembuatan Susu Kefir

Pada sesi ini pemateri menyampaikan Susu Kefir Merupakan Salah Satu Jenis Susu Fermentasi, yang Pertama kali ditemukan di Pegunungan Kaukasus Bagian Rusia Barat Daya. Selain itu juga pemateri menyampaikan prosedur pembuatan susu kefir.

c. Pemasaran Offline dan Online (konsep pemasaran, manfaat dan media pemasaran)

Melihat perkembangan Digital hingga saat ini yang sangat signifikan, telah menciptakan pola kehidupan yang baru di masyarakat. Ketergantungan seseorang terhadap internet agaknya 
sudah menjadi budaya baru.Ada yang ber Sosmed ria, ada yang cek email, video streaming, chatting dan sebagainya.

Bisnis Offline jelas membutuhkan persiapan yang matang untuk modal. Anda harus menyiapkan modal untuk sewa gedung yang semakin hari semakin mahal. Harus siapkan modal untuk beli barang yang akan anda jual di bisnis Offline anda.

Bisnis Offline bisa menjual berbagai jenis barang dalam satu toko, namun tentunya akan terbatas pada tempat dan penyediaan stock barangnya dan jika barang yang di sediakan sangat banyak dan beragam, artinya anda memerlukan modal yang tidak sedikit juga.

Pemateri memaparkan media promosi online seperti Google My Bussnies, Gmail, Google Kalender, Instagram, Facebook, WhatsApp Bussine, Youtube, Line dan E- Commerce.

d. Contoh Aneka Olahan Produk Kefir

Pada sesi ini, pemateri memberikan contoh-contoh produk olahan susu kefir seperti lulur kecantikan, sabun, toner pembersih wajah, masker wajah untuk kecantikan dan minuman kesehatan yang telah diproduksi sebelumnya dan telah digunakan oleh masyarakat.

\section{Simpulan Dan Saran}

Berdasarkan hasil, dan rencana tahap berikutnya maka kesimpulannya adalah pengabdian masyarakat ini telah melakukan program dengan bentuk kerjasama yang solid antara mitra, pemerintahtah desa, dan masyarakat setempat. Selain itu, program abdimas ini membahas empat materi penting diantaranya: segudang manfaat susu kefir, prosedur pembuatan susu kefir, pemasaran offline dan online (konsep pemasaran, manfaat dan media pemasaran), contoh aneka olahan produk kefir. Tahap pelaksanaan program pengabdian masyarakat ini terdiri dari tiga tahap : tahap sosialisasi dan cek lokasi, tahap pelaksanaan dan tahap evaluasi. Target luaran capaian program abdimas ini telah terlaksana $80 \%$, publis artikel di jurnal tidak terakreditas masih dalam bentuk draft siap publis. Dengan adanya kegiatan ini, pengetahuan masyaratakat meningkat dengan dengan selisih nilai rata-rata 1,88 dengan penambahan pengetahuan mencapai $9,4 \%$.

\section{Daftar Rujukan}

Abubakar. (2012). Mendukung Standardisasi dan Keamanan Susu Segar di Indonesia. Balai Besar Litbang Pascapanen Pertanian Bogor, 1-12.

Hendrawati, T. Y., \& Utomo, S. (2017). Optimasi suhu dan waktu sterilisasi pada kualitas susu segar di kabupaten boyolali, 9(2), 97-102.

Resnawati, H. (n.d.). Kualitas Susu Pada Berbagai Pengolahan dan Penyimpanan ( The Quality of Milk and its Products on Several Processing and Storage ). Balai Penelitian Ternak Bogor, 497-502.

Reza, F. (2016). Strategi Promosi Penjualan Online Lazada.co.id. Jurnal Kajian Komunikasi, 4/1(1), 1-10. https://doi.org/10.24198/jkk.vol4n1.6

Safitri, M. F., \& Swarastuti, A. (2011). Kualitas Kefir Berdasarkan Konsentrasi Kefir Grain. Jurnal Aplikasi Teknologi Pangan Fakultas Peternakan Universitas Diponegoro, 08(24), 24-29.

Usmiati, S., \& Ram, R. (2005). Mikroba Susu Fermentasi Sejenis Kefir Menggunakan Starter Kombinasi Penyusun Granula Kefir dan Bifidobacterium longum, 10(1), 27-34.

Yusuf, A. (2011). Tingkat Kontaminasi Escherichia coli pada Susu Segar di Kawasan Gunung Perak Kabupaten Sinjai. Universitas Hasanuddin. 